\title{
First record of Grey Gull Leucophaeus modestus in Brazil
}

\author{
Henrique Chupil ${ }^{1,2}$, Veronica Marques ${ }^{1}$, Shany Nagaoka ${ }^{1} \&$ Rafael Sardinha Murro $^{1}$ \\ Instituto de Pesquisas Cananéia, Cananéia, SP, Brazil. \\ 2 Corresponding author: hchupil@gmail.com
}

Received on 26 April 2019. Accepted on 04 July 2019.

\begin{abstract}
We report the first record of Grey Gull (Leucophaeus modestus) in Brazil. On 21 April 2019 at 08:31 h, the secondcycle bird was photographed walking near a small stream that flows into the sea on Ilha Comprida, state of São Paulo, southeastern coast of Brazil. The occurrence of a single individual on the Atlantic coast of the South American continent lead us to propose that the species is a vagrant in Brazil.
\end{abstract}

KEY-WORDS: beach monitoring, Ilha Comprida, Lariidae, new record, vagrant species.

Grey Gull Leucophaeus modestus has a restricted distribution to the western region of Central and South America, occurring in Ecuador (Mills 1967, Santander et al. 2013), Peru (Hughes 1968, Pulldo et al. 1996, Valega 2007) and Chile (Barros et al. 2015). There are also occasional records in Costa Rica (Sandoval \& Sánchez 2012), Argentina (Carrillo 2015) and Colombia (Estela et al. 2010). In the Atlantic portion of the American Continent its occurrence is sporadic, with records on Falkland Islands in 1953 and 1991 (Carrillo 2015).

Grey Gull is commonly found in coastal areas, foraging directly on the sea surface (Duffy 1980) or along the shoreline (Howell et al. 1974). During the breeding period it moves inland, nesting in a distant desert region in Chile, up to $100 \mathrm{~km}$ from the coast (Erize et al. 2006). It is one of the few bird species adapted to nest in the Atacama Desert (Chile), considered the world's driest environment (Aguilar et al. 2012). The species' nesting site was described only in 1943 by Goodall \& Johnson (1945) in a desert area in the province of Antofagasta (Chile), answering one of the major questions on the species ecology.

There are nine Gull species recorded in Brazil: three resident species, three visitors from the north or south and three vagrant species (Piacentini et al. 2015). This article presents the first documented record of Grey Gull for the Brazilian territory.

During daily monitoring of beaches performed by Instituto de Pesquisas Cananéia for Projeto de Monitoramento de Praias - Bacia de Santos (PMPBS), which covers the coasts of the states of São Paulo, Paraná and Santa Catarina, the bird was first recorded on 21 April 2019 at 08:31 h. It was observed walking on the beach at the northern portion of Ilha Comprida $\left(24^{\circ} 42^{\prime} 27.8^{\prime \prime} \mathrm{S} ; 4^{\circ} 28^{\prime} 16.8^{\prime \prime} \mathrm{W}\right)$, on the southern coast of the state of São Paulo, southeastern Brazil (Fig. 1). Faced with the researchers' approach, the bird had difficulties to fly, trying to run away. The bird was detected during three other consecutive days, moving to the south $(5 \mathrm{~km}$ away from the first location).

This is a second-cycle bird, since it was gray with brownish shades (Figs. 2A \& B), differing from adults with grayish plumage, whose head is whitish during the reproductive period (Harrison 1983). Another characteristic that proves this bird to be second-cycle is the end of the secondary feathers presenting a white band (Harrison 1983). Other diagnostic characteristics contributed to the species identification, such as the beak, feet, tarsus and black end of wings contrasting with gray plumage, as well as the previously mentioned white band at the end of the secondary feathers, which is absent in young birds (Harrison 1983, Erize et al. 2006; Fig. 2C).

The occurrence of Grey Gull in the Brazilian coast can be interpreted as an occasional event, due to the absence of previous records and the fact that the species is typical of the western part of the continent, occurring mainly in Chile, Peru and Ecuador (BirdLife International 2019). The bird observed probably hit the Atlantic coastline in one of two main ways: moving inland though the continent, or bordering the coast.

The first hypothesis is supported by the fact that the species reproduces in desert areas in the interior of Chile (Barros et al. 2015), approximately $2000 \mathrm{~km}$ distant, in a straight line, from the coast of São Paulo. However, 


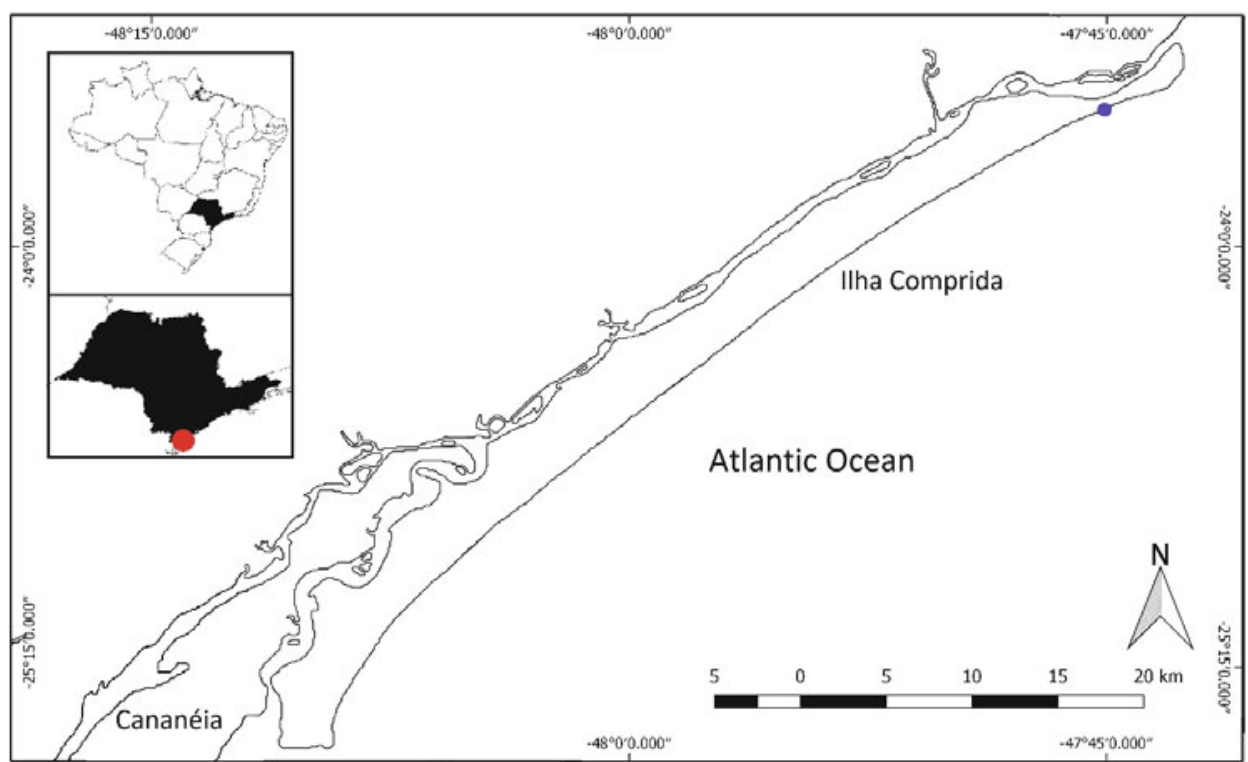

Figure 1. Map of the place where the Grey Gull (Leucophaeus modestus) was first registered (blue circle) on Ilha Comprida, state of São Paulo, southeast Brazil.

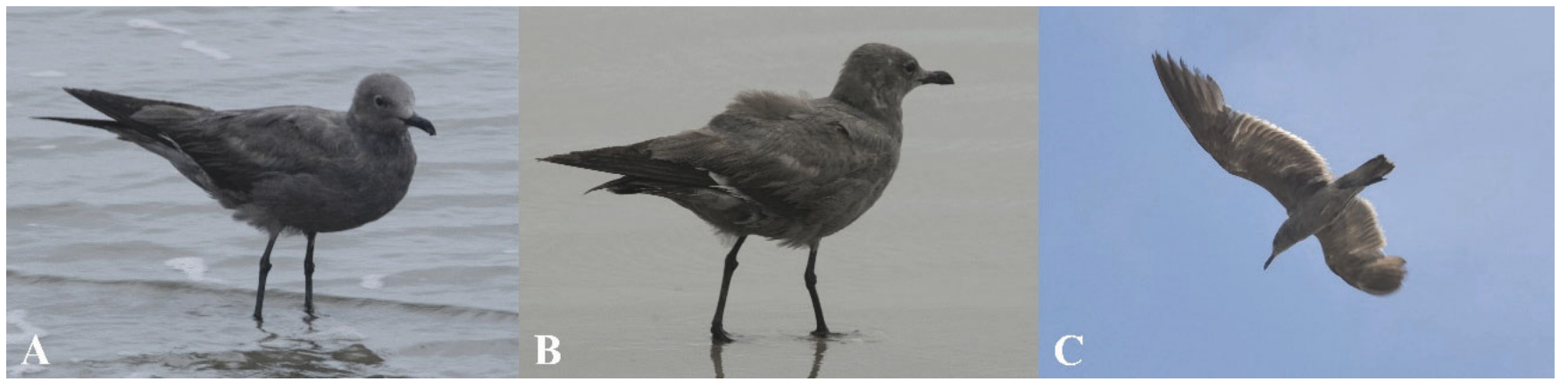

Figure 2. Grey Gull (Leucophaeus modestus) registered on Ilha Comprida, southeastern Brazil. Detail of gray plumage with brownish shades (A \& B ) and white strip on the secondary remnants visible in flight $(\mathbf{C})$ that characterized this species. Photo author: Rafael Murro Sardinha (A \& B), Kelly Panssard (C).

to do this, the bird would cross the Andes. Goodall \& Johnsons (1945) report Grey Gull nesting in altitudes of up to $2335 \mathrm{~m}$ and the recent record for Argentina in Salta also supports that the bird can fly up to $4300 \mathrm{~m}$ (Carillo 2015). This suggests that the species could fly in high altitudes and consequently surpass the mountain range in its lowest sectors.

The second possible route would be flying along the coast from the south. This is also supported by literature, since Carrillo (2015) cites two records of the species on the Falkland Islands. Thus, the individual may have crossed from the Pacific to the Atlantic Ocean in the southernmost portion of the continent through Argentina and then moved up along the coast to São Paulo.

Within the Lariidae family, species recorded in Brazil such as Sabine's Gull (Xema sabini, Lees et al. 2014), Laughing Gull (Leucophaeus atricilla, Lima et al. 2010), Franklin's Gull (Leucophaeus pipixcan, Dias et al. 2010), Lesser Black-backed Gull (Larus fuscus, Girão et al. 2006), Olrog's Gull (Larus atlanticus, Belton 1984) and Ring-billed Gull (Larus delawarensis, Sick 1979) can move to locations far from their breeding areas. These species are considered seasonal visitors (L. atricilla and $L$. atlanticus) or vagrant (X. sabini, L. pipixcan and L. fuscus) in Brazil (Piacentini et al. 2015). Thus, Grey Gull would also be considered vagrant, since its record in Brazil is punctual.

We report a relevant record for Brazilian avifauna, since the occurrence of Grey Gull draws attention to the fact that the species has moved quite a lot from where it naturally occurs. Vagrancy in birds is commonly explained by the presence of species in population expansion (Veit 2000, Lees \& Gilroy 2009), pursuit of resources (Berthold 1993, Lees \& Gilroy 2009) and disorientation caused by natural or anthropogenic events (Patten \& Marantz 1996, Gilroy \& Lees 2003, Pfeifer et al. 2007). With regard to the climatic interference in the life cycle of Grey Gull, Aguilar et al. (2016) cites that the reproductive season of 2014-2015 was influenced by the climatic phenomenon El Niño, which caused a reduction in the availability of 
resources and led the species to reproduce in areas closer to the coast. Thus, in the present case, we can speculate that its occurrence in southeastern Brazil may have been influenced by some climatic weather that could have disoriented the bird, which could explain the fact that it took the bird some time to fly away after the approach of the team. Another possibility is simply that the bird dispersed from its original area of occurrence searching for food. Thus, both cases reinforce the fact that the species is considered vagrant.

\section{ACKNOWLEDGEMENTS}

We thank Projeto de Monitoramento de Praias - Bacia de Santos (PMP-BS) and Instituto de Pesquisas Cananéia (IPeC) for monitoring the south coast of the state of São Paulo (License MMA/IBAMA: 640/2015), which enabled this species record. Thanks also to Kelly Panssard for enabling one of the photographs presented here.

\section{REFERENCES}

Aguilar R., Perucci M., Cisternas T., Torres M., Silva M., Marín A., Silva A. \& Bolados P. 2012. La nidificación de la Gaviota Garuma y su vulnerabilidad a las actividades antrópicas en el Desierto de Atacama. Santiago: Fondo de Protección Ambiental.

Aguilar R., Simeone A., Rottmann J., Perucci M. \& Luna-Jorquera G. 2016. Unusual coastal breeding in the desert-nesting Gray Gull (Leucophaeus modestus) in northern Chile. Waterbirds 39: 69-74.

Barros R., Jaramillo A. \& Schmitt F. 2015. Lista de las aves de Chile 2014. La Chiricoca 20: 79-100.

Belton W. 1984. Birds of Rio Grande do Sul, Brazil: part 1, Rheidae through Furnariidae. Bulletin of the American Museum of Natural History 178: 371-631.

Berthold P. 1993. Bird migration, a general survey. Oxford: Oxford University Press.

Birdlife International. 2019. Species factsheet: Larus modestus. http:// www.birdlife.org (Access on 24 April 2019).

Carrillo S.M. 2015. Primer registro de Gaviota Garuma (Leucophaeus modestus) en territorio continental argentino. EcoRegistros 5: 1011.

Dias R.A., Agne C.E., Gianuca D., Gianuca A., Barcellos-Silveira A. \& Bugoni L. 2010. New records, distribution and status of six seabird species in Brazil. Iheringia, Série Zoologia 100: 379-390.

Duffy D.C. 1980. Patterns of piracy by Peruvian seabirds: a depth hypothesis. Ibis 122: 521-525.

Erize F., Mata J.R.R. \& Rumboll M. 2006. Birds of South America: non-passerines (rheas to woodpeckers). Princeton: Princeton University Press.

Estela F.A., López-Victoria M., Castillo L.F. \& Naranjo L.G. 2010.
Status of knowledge on seabirds in Colombia after 110 years of research. Boletin SAO 20: 2-21.

Gilroy J.J. \& Lees A.C. 2003. Vagrancy theories: are autumn vagrants really reverse migrants? British Birds 96: 427-438.

Girão W., Albano C., Pinto T., Campos A., Meirelles A.C. \& Silva C.P.N. 2006. First record of the Lesser Black-backed Gull Larus fuscus Linnaeus, 1758 for Brazil. Ararajuba 14: 463-464.

Goodall J.D. \& Johnson A.W. 1945. Nesting habits of the Peruvian Gray Gull. Auk 62: 450-452.

Harrison P. 1983. Seabirds: an identification guide. Boston: Houghton Mifflin Company.

Howell T.R., Araya B. \& Millie W.R. 1974. Breeding biology of the Gray Gull Larus modestus. University of California Publications of Zoology 104: 1-57.

Hughes R.A. 1970. Notes on the birds of the Mollendo district, southwest Peru. Ibis 112: 229-241.

Lees A.C. \& Gilroy J.J. 2009. Vagrancy mechanisms in passerines and near-passerines, p. 124-209. In: Slack R. (ed.). Rare birds, where and when: an analysis of status and distribution in Britain and Ireland. New York: Rare Birds Books.

Lees A.C., Távora A.F., Tavares M., Távora A. \& Coutinho D. 2014. A second Sabine's Gull Xema sabini in Brazil. Bulletin of the British Ornithologists' Club 134: 163-164.

Lima L.M., Schunck F., Siciliano S., Carlos C.J., Rennó B., Fonseca-Neto F.P., Fedrizzi C.E., Albano C. \& Moura J.F. 2010. Distribuição, abundância e sazonalidade de Leucophaeus atricilla (Charadriiformes: Laridae) no Brasil. Revista Brasileira de Ornitologia 18: 199-206.

Mills E.L. 1967. Bird records from southwestern Ecuador. Ibis 109: 534-538.

Patten M.A. \& Marantz C.A. 1996. Implications of vagrant southeastern vireos and warblers in California. Auk 113: 911-923.

Pfeifer R., Stadler J. \& Brandl R. 2007. Birds from the far east in central Europe: a test of the reverse migration hypothesis. Journal of Ornithology 148: 379-385.

Piacentini V.Q., Aleixo A., Agne C.E., Maurício G.N., Pacheco J.F., Bravo G.A., Brito G.R.R., Naka L.N., Olmos F., Posso S., Silveira L.F., Betini G.S., Carrano E., Franz I., Lees A.C., Lima L.M., Pioli D., Schunck F., Amaral F.R., Bencke G.A., Cohn-Haft M., Figueiredo L.F.A., Straube F.C. \& Cesari E. 2015. Annotated checklist of the birds of Brazil by the Brazilian Ornithological Records Committee. Revista Brasileira de Ornitologia 23: 91-298.

Pulldo V., Jahncke J., Makamatsu P. \& Flores C. 1996. Conservation of Charadriiformes on the Peruvian coast. International Wader Studies 8: 55-61.

Sandoval L. \& Sánchez J.E. 2012. Lista de aves de Costa Rica. San José: Unión de Ornitólogos de Costa Rica.

Santander T., Ágreda A. \& Lara A. 2013. Censo Neotropical de aves acuáticas, Ecuador 2008-2012. Quito-Ecuador: Aves y Conservación.

Sick H. 1979. Migração de aves no Brasil. Brasil Florestal 9: 7-10.

Valega R.C. 2007. Avifauna of a relict mangrove forest in San Pedro, dpto. Piura, Perú. Cotinga 27: 42-47.

Veit R.R. 2000. Vagrants as the expanding fringe of a growing population. Auk 117: 242-246.

Associate Editor: Leandro Bugoni. 